\title{
Early Detection of Hepatitis by Using Certainty Factor
}

\author{
Andri Permana Wicaksno* \\ Health Department \\ Politeknik Negeri Jember \\ Jember, Indonesia \\ andri_permana@polije.ac.id
}

\author{
Demiawan Rachmatta Putro Mudiono \\ Health Department \\ Politeknik Negeri Jember \\ Jember, Indonesia \\ demiawanrpm@polije.ac.id
}

\begin{abstract}
Artificial Intelligence (AI) is intelligence that is added to a system that can be set in a scientific context or can be called artificial intelligence, the ability of a system application to generate external data correctly, use learning to learn from data, and use it to achieve goals, specific tasks through adaptations contained in external. The purpose of this study is to develop a decision support system in early detection of hepatitis using artificial intelligence based on android Hepatitis is a virus that causes inflammation of the liver and can cause severe damage over time. The most common types are hepatitis $A$ and $B$ but hepatitis can also be caused by our immune system (autoimmune hepatitis). Common symptoms of hepatitis are yellow skin or jaundice. The method of early detection of the type of hepatitis in this study uses certainty factor. The result of this study is to provide accurate information in early detection of hepatitis type based on the patient's evidence.
\end{abstract}

Keywords-artificial intelligence, hepatitis, certainty factor

\section{INTRODUCTION}

The development of technology in the globalization era nowadays has increased rapidly. Almost all fields have been influenced by development aartificial iintelligent, for example, in education, business, health, or others. The development also becomes one of the government ways to change the industrial mindset called industrial revolution 4.0 [1].

There is a unique characteristic in Industry 4.0 which is the application of artificial intelligence. One of the application forms is the using of robot replacing human and also by the existence of a Smartphone-based application so that the early detection can be done with low cost, fast, effectively and efficiently [2]

Artificial Intelligence has made a significant improvement that enable machine to automatically represent and explain complicated data [3]

Hepatitis is a virus that cause liver inflammation and along with the time can cause a severe damage. The most common types of Hepatitis are Hepatitis A and B. However, hepatitis can also be caused by our immune system (hepatitis autoimmune). Hepatitis is one of the diseases in tropical country [5]

Hepatitis can appear along with the symptom like yellow disease (skin and eyes turn to yellow), dark urine, fatigue, nausea, vomiting, fever, and stomachache [6]. WHO has 5 strategies in giving preventive actions to the hepatitis sufferers. One of them is about improving a powerful information system to understand the epidemic character of hepatitis virus and focus on the sufferers [7]. The development of information system in doing early detection of hepatitis virus character type is needed most in realizing the WHO strategies. It needs an expert to take part in the development of a hepatitis virus type early detection

Indonesia has a high number of hepatitis case sufferers, the incidence in 2018 was around 1,017,290 cases of hepatitis. Meanwhile, seen from the province of East Java, the incidence of hepatitis cases was around 151,878 cases. This figure is the second highest figure before West Java province with the incidence of hepatitis cases 186,809 cases

\section{METHOD}

\section{A. Analysis of requirements for Early Detection of Hepatitis}

Analysis of system requirements is carried out to find out what requirements needed by the system that will be made by collecting data related with development of decision support system in early detection of hepatitis using android based artificial intelligence. Analysis of requirements can be complaints or what symptoms and also the laboratory checkup result that is useful to predict a hepatitis disease suffered by a patient.

\section{B. Desigining System}

\section{1) Determining system and laboratory}

Determining symptom can be carried out by the researchers finding literature about what symptoms that each hepatitis type has and how the way to do screening for hepatitis disease is. Furthermore, data obtained will be adjusted by some experts related to the disease; specialist doctor, general practitioner, and nurse.

2) Calculation of symptoms and laboratory results using Certainty Factor method

Certainty Factor model is a method to manage uncertainty in the rule-based system. Certainty Factor is defined as the following equation [12]:

$$
\mathrm{CF}(\mathrm{H}, \mathrm{E})=\mathrm{MB}(\mathrm{H}, \mathrm{E})-\mathrm{MD}(\mathrm{H}, \mathrm{E})
$$

$\mathrm{CF}(\mathrm{H}, \mathrm{E})$ : Certainty Factor of hypothesis $\mathrm{H}$ influenced by symptom $\mathrm{E}$. The value of $\mathrm{CF}$ is around -1 until 1 . Value -1 shows absolute disbelief, while value 1 shows absolute belief. 
MB (H, E): measurement of increased belief to hypothesis $\mathrm{H}$ influenced by symptom $\mathrm{E}$.

MD (H, E): measurement of increased disbelief to hypothesis $\mathrm{H}$ influenced by symptom $\mathrm{E}$.

Certainty Factor is for similarly concluded rules: CFcombine $\mathrm{CF}[\mathrm{H}, \mathrm{E}] 1,2=\mathrm{CF}[\mathrm{H}, \mathrm{E}] 1+\mathrm{CF}[\mathrm{H}, \mathrm{E}]^{2} *(1-\mathrm{CF}$ $\left.[\mathrm{H}, \mathrm{E}]^{1}\right)$

If $\mathrm{CF}$ value that will be calculated is more than two, it is defined by the following equation:

CFcombine $\mathrm{CF}[\mathrm{H}, \mathrm{E}]_{\mathrm{old}}, 3=\mathrm{CF}[\mathrm{H}, \mathrm{E}]_{\mathrm{old}}+\mathrm{CF}[\mathrm{H}, \mathrm{E}] 3^{*}$ (1-CF [H, E] old

\section{3) Applying System}

The next is the implementation step which is the step of making the program carried out by transforming analysis result obtained in the previous system design. Implementation system is carried out by scripting by using Android.

\section{RESULTS AND DISCUSSION}

\section{A. Analysis of requirements for Early Detection of Hepatitis}

In this step, it explains about what requirements in early detection of hepatitis. Hepatitis has some type, which are hepatitis type A and hepatitis type B. The type of hepatitis is distinguished based on virus, symptoms, mode of transmission, and laboratory result.

\section{1) Hepatitis A.}

Hepatitis A virus is a disease with global distribution. Prevalence of infection which is marked by the increase of anti-HAV antibody has been known universally and has tight relation with the standard of sanitation/health of the involved area. Hepatitis A virus is transmitted by air and food which is polluted. Hepatitis A transmission happens by faecal-oral which is through food and drink polluted by hepatitis virus. Diagnosis is enforced based on clinical symptom and helped by laboratory checking supporting means. Anamneses: prodromal symptom, contact history. Physical checking: yellow colour can be seen easily in sclera, skin, mucous membrane of the roof of the mouth, in the severe case (fulminant). There is a mouth which has specific smell (foeter hepaticum). Laboratory Check: heart functioning test (there is an increase of bilirubin, SGPT and sometimes it is along with the increase of GGT, phosphatise alkali), and anti HAV serology test, which is IgM anti HAV which has positive value [13].

\section{2) Hepatitis $B$.}

Hepatitis B is usually transmitted from one person to the others through blood (receiver of blood product, hemodialisa patient, health officer, or exposed to blood). Hepatitis B virus is found in the body fluid that has high concentration of hepatitis B virus like semen, secret servicovaginal, saliva and other body fluid which can transmit hepatitis B by sexual transmittion. other transmittion way is through tissue penetration (perkutan) or through tools that is polluted with hepatitis B virus like comb, razor, cutlery, tooth brush, tatoo, acupuncture, piercing, medical tools, and others. Other transmission way is by maternal-neonatal and maternal-infant transmission, however there has not been evidence of fekaloral spreading yet. Hepatitis B has various symptom from without symptom until severe symptom like blood vomiting and coma. Severe hepatitis has almost low grade symptom such as influenza symptom like low grade fever, nausea, feeling weak, lost apetite, eyes turn to yellow, dark urine, diarrhea, and muscular pain. In severe hepatitis B, there is a bigger ALT increase than the AST increase which has ALT rate $20-50$ times of normal. $\operatorname{IgM}$ anti $\mathrm{HBc}$ is also found in the blood beside HBsAg, HBeAg, and HBV DNA. In order to reach a high seroconversion level and concentration of protective anti-HBs $(10 \mathrm{mIU} / \mathrm{ml})$, immunization is given three times at 0,1 , and 6 months.

B. Designing System

1) Deterimining Symptoms

TABLE I. SYMPTOM

\begin{tabular}{|c|c|c|}
\hline \multirow{2}{*}{ Symptoms } & \multicolumn{2}{|c|}{ Hepatitis } \\
\hline & A & B \\
\hline Symptoms like flu & $*$ & $*$ \\
\hline Feeling tired & $*$ & * \\
\hline Fever & $*$ & $*$ \\
\hline Diarrhea & $*$ & \\
\hline Nausea & $*$ & $*$ \\
\hline Stomach pain & $*$ & \\
\hline Eyes turn to yellow & $*$ & $*$ \\
\hline Lost appetite & $*$ & \\
\hline Weak & & $*$ \\
\hline Lethargic & $*$ & * \\
\hline Muscular pain & $*$ & $*$ \\
\hline low grade fever & & $*$ \\
\hline Skin turns to yellow & & * \\
\hline Dark urine & $*$ & $*$ \\
\hline Vomiting & $*$ & $*$ \\
\hline Stomachache & & * \\
\hline Headache & & $*$ \\
\hline \multicolumn{3}{|l|}{ Aches } \\
\hline Dizziness & $*$ & $*$ \\
\hline Reddish urine & $*$ & \\
\hline The white part of eye ball turns yellowish & $*$ & \\
\hline Pain in the joints & $*$ & $*$ \\
\hline Strange feeling in the throat & $*$ & \\
\hline The appearance of jaundice for several days & $*$ & \\
\hline rash & & $*$ \\
\hline shiver & & \\
\hline \multicolumn{3}{|l|}{ Pain in the right side of stomach } \\
\hline \multicolumn{3}{|l|}{ Unexplained weight loss } \\
\hline \multicolumn{3}{|l|}{ Unclear abdominal disorder } \\
\hline Liquid feces & & \\
\hline
\end{tabular}

TABLE II. LABORATORY TEST

\begin{tabular}{|c|c|c|}
\hline \multirow{2}{*}{ Blood test } & \multicolumn{2}{|c|}{ Hepatitis } \\
\cline { 2 - 3 } & A & B \\
\hline SGOT & $*$ & $*$ \\
\hline SGPT & $*$ & $*$ \\
\hline ELISA & & \\
\hline Hbsag & & \\
\hline Hbeag & & $*$ \\
\hline
\end{tabular}


2) Calculation of symptoms and laboratory test using Certainty Factors method

$\mathrm{CF}$ value data are obtained from the reduction between $M B$ value and MD value. CF value data are used in the process of consulting calculation that is used by user. Weight for $\mathrm{MB}$ value can be seen in table 3 and weight for MD value can be seen in table 4.

TABLE III. MB VALUe WeIGHT

\begin{tabular}{|c|c|c|}
\hline No & Information & MB Value \\
\hline 1 & very sure & 1 \\
\hline 2 & sure & 0.8 \\
\hline 3 & sure enough & 0.6 \\
\hline 4 & less sure & 0.4 \\
\hline 5 & have no idea & 0.2 \\
\hline 6 & not sure & 0 \\
\hline
\end{tabular}

TABLE IV. MD VALUE WeIGHT

\begin{tabular}{|c|c|c|}
\hline No & Information & MD Value \\
\hline 1 & very sure & $0.11-0.15$ \\
\hline 2 & sure & $0.06-0.10$ \\
\hline 3 & less sure & $0-0.05$ \\
\hline
\end{tabular}
data:

The following is the case study of hepatitis diagnosis basic

A patient named Mrs. S is 56 years old, $60 \mathrm{~kg}$ of weight, and $152 \mathrm{~cm}$ of height. The patient is diagnosed with hepatitis B. The last laboratory check result shows the rate of SGOT $=$ $60 \mathrm{U} / \mathrm{L}$ and SGPT $=88 \mathrm{U} / \mathrm{L}$, uric acid $=8.2 \mathrm{mg} / \mathrm{dl}$, albumin $=$ $4,4 \mathrm{mg} / \mathrm{dl}$ and the HBsAg check result is positive. The patient feels nausea, dizziness, and looks pale. The patient's temperature is 37 degree $\mathrm{C}$, and the blood pressure is $118 / 80$ $\mathrm{mmHg}$.

From the above statement it can be concluded that the patient Mrs. S, aged 60, was diagnosed with hepatitis B. The blood test results showed SGOT $=60 \mathrm{U} / \mathrm{L}$, which is normally 3-45U / L and SGPT $=80 \mathrm{U} / \mathrm{L}$, which is normally $0-35 \mathrm{U} / \mathrm{L}$. Positive HBsAg examination. Symptoms experienced by nausea, dizziness or headache, and fever.

Based on the above statements, it can be concluded that the patient, Mrs. S, with the age of 60 years old is diagnosed to suffer hepatitis B. The blood test result shows SGOT $=60$ $\mathrm{U} / \mathrm{L}$ higher than the normal condition which is $3-45 \mathrm{U} / \mathrm{L}$ and $\mathrm{SGPT}=80 \mathrm{U} / \mathrm{L}$ higher than the normal condition which is 0 $35 \mathrm{U} / \mathrm{L}$. HBsAg check is positive. She has nausea, dizziness, or headache, and fever.

TABLE V. CHOSEN SYMPTOMS

\begin{tabular}{|c|c|c|c|c|}
\hline & MB_A & MD_A & MB_B & MD_B \\
\hline Fever & 0.6 & 0.02 & 0.6 & 0.02 \\
\hline Nausea & 0.6 & 0.02 & 0.6 & 0.02 \\
\hline Headache & 0.2 & 0.02 & 0.6 & 0.05 \\
\hline
\end{tabular}

Calculating evidence value of $\mathrm{MB}$ and $\mathrm{MD}$ from the chosen symptoms and then there will be $\mathrm{CF}$ symptom obtained from MB value minus MD value.

$$
\begin{aligned}
& \text { MB_A } 12=\text { MB_A }+ \text { MB_A } A_{2} *\left(1-\mathrm{MB} \_\mathrm{A}\right) \\
& =0.6+0.6^{*}(1-0.6)=0.84 \\
& \mathrm{MB} \_\mathrm{A}_{\mathrm{g}} \quad \mathrm{MB} \_\mathrm{A}_{12}+\mathrm{MB} \_\mathrm{A}_{3} *\left(1-\mathrm{MB} \_\mathrm{A}_{12}\right) \\
& =0.84+0.2 *(1-0.84)=0.864 \\
& =\text { MD_A }+ \text { MD_A } 2 *\left(1-M D \_A\right) \\
& =0.02+0.02 *(1-0.02)=0.0396 \\
& \text { MD_A } \quad=M D \_A_{12}+M D \_A_{3} *\left(1-M D \_A_{12}\right) \\
& =0.0396+0.2 *(1-0.0396)=0.23168 \\
& =\text { MB_Ag }- \text { MD_Ag } \\
& =0.864-0.23168 \\
& =0.64 \\
& \mathrm{MB} \_\mathrm{B}_{12} \quad=\mathrm{MB} \_\mathrm{B}+\mathrm{MB} \_\mathrm{B}_{2} *\left(1-\mathrm{MB} \_\mathrm{B}\right) \\
& =\mathrm{MB} \_\mathrm{B}_{12}+\mathrm{MB} \_\mathrm{B}_{3} *\left(1-\mathrm{MB} \_\mathrm{B}_{12}\right) \\
& =0.84+0.6 *(1-0.84)=0.936 \\
& =\mathrm{MD} \_\mathrm{B}+\mathrm{MD} \_\mathrm{B}_{2} *\left(1-\mathrm{MD} \_\mathrm{B}\right) \\
& =0.02+0.02 *(1-0.02)=0.0396 \\
& =\text { MD_B } 12+\mathrm{MD} \_\mathrm{B}_{3} *\left(1-\mathrm{MD} \_\mathrm{B}_{12}\right) \\
& =0.0396+0.05 *(1-0.0396)=0.0876 \\
& \text { = MB_B } \mathrm{B} \text { - MD_B } \mathrm{g} \\
& =0.936-0.0876 \\
& =0.84
\end{aligned}
$$

TABLE VI. CHOSEN LABORATORY TEST

\begin{tabular}{|c|c|c|c|c|}
\hline & MB_A & MD_A & MB_B & MD_B \\
\hline SGOT & 0.6 & 0.03 & 0.6 & 0.05 \\
\hline SGPT & 0.6 & 0.03 & 0.6 & 0.05 \\
\hline Hbsag & 0 & 0.06 & 0.8 & 0.11 \\
\hline
\end{tabular}

Calculating evidence value of $\mathrm{MB}$ and $\mathrm{MD}$ from the laboratory test and then there will be CF symptom obtained from MB value minus MD value.

$$
\begin{aligned}
& \mathrm{MB} \_\mathrm{A}_{\mathrm{t}} \quad=\mathrm{MB} \_\mathrm{A}+\mathrm{MB} \_\mathrm{A}_{2} *\left(1-\mathrm{MB} \_\mathrm{A}\right) \\
& =0.6+0.6 *(1-0.6)=0.84 \\
& \mathrm{MB} \_\mathrm{A}_{\mathrm{t}} \quad \mathrm{MB} \_\mathrm{A}_{\mathrm{t}}+\mathrm{MB} \_\mathrm{A}_{3} *\left(1-\mathrm{MB} \_\mathrm{A}_{\mathrm{t}}\right) \\
& =0.84+0 *(1-0.84)=0.84 \\
& \text { MD_A } 1 \text { = MD_A+MD_A } 2 *\left(1-M D \_A\right) \\
& \begin{array}{ll} 
& =0.03+0.03 *(1-0.03)=0.033 \\
& =M D A_{t}
\end{array} \\
& \text { CF_At } \quad=\text { MB_A } A_{t}-\text { MD_A } \\
& =0.84-0.64 \\
& =0.21 \\
& \text { MB_B } \mathrm{B}_{\mathrm{t}} \quad=\mathrm{MB} \_\mathrm{B}+\mathrm{MB} \_\mathrm{B}_{2} *\left(1-\mathrm{MB} \_\mathrm{B}\right) \\
& =0.6+0.6 *(1-0.6)=0.84 \\
& \text { MB_B } B_{t} \quad=M B \_B_{t}+M B \_B B_{3} *\left(1-M B \_B_{t}\right) \\
& \text { MD_B } \quad=\text { MD_B+MD_B }{ }^{*} *\left(1-M D \_B\right) \\
& \begin{array}{l}
=0.05+0.05 *(1-0.05)=0.0975 \\
=M D \_B_{t}+M D \_B 3 *\left(1-M D \_B_{t}\right)
\end{array} \\
& =0.0975+0.11 *(1-0.0975)=0.2 \\
& \text { CF_Bt } \quad \text { MB_B }- \text { MD_B } t \\
& =0.97-0.19 \\
& =0.78
\end{aligned}
$$


The final step to calculate $\mathrm{CF}_{\text {combine }}$ is obtained from the calculation of CF symptom with the CF laboratory test.

$$
\begin{aligned}
\mathrm{CFCA} & =\mathrm{CFA}_{\mathrm{g}}+\mathrm{CFA}_{\mathrm{t}} *\left(1-\mathrm{CFA}_{\mathrm{g}}\right) \\
& =0.64+0.21 *(1-0.64) \\
& =0.72
\end{aligned}
$$

So, the value of $\mathrm{CF} A=0.72$

$$
\begin{aligned}
\mathrm{CFCB} & =\mathrm{CFB}_{\mathrm{g}}+\mathrm{CFB}_{\mathrm{t}}^{*}\left(1-\mathrm{CFB}_{\mathrm{g}}\right) \\
& =0.84+0.78 *(1-0.84) \\
& =0.97
\end{aligned}
$$

\section{So, the value of $C F B=0.97$}

From the manual calculation that is carried out, it is obtained that $\mathrm{CF} B$ is the highest with the value of $\mathrm{CF}=0.97$ or $97 \%$ in early detection of hepatitis type B.

C. Applying System

\section{1) Flowchart System}

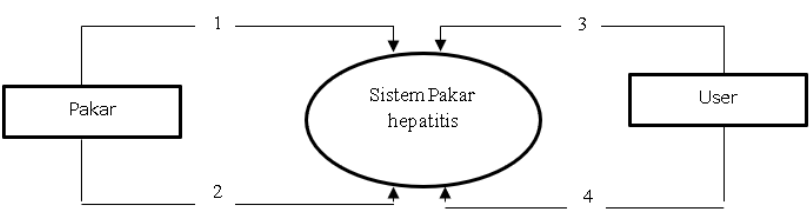

Fig. 1. Flowchart System

Information:

a) Input the symptom and laboratory test of hepatitis

b) Show the list of symptom and laboratory test

c) Answer questions which are in the expert system

d) Give early detection of hepatitis type suffered by patients

2) Implementation

- Design interface login and register

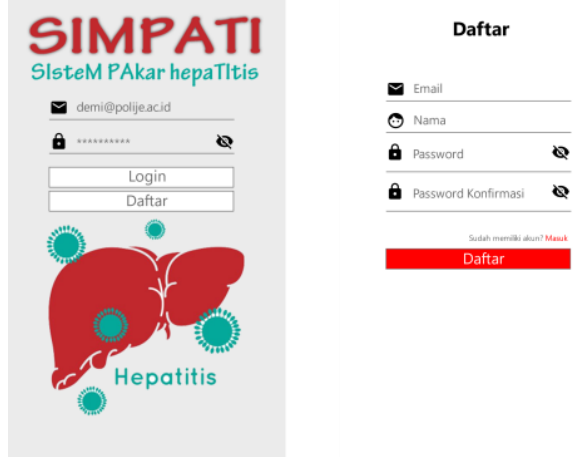

- Design interface home and about
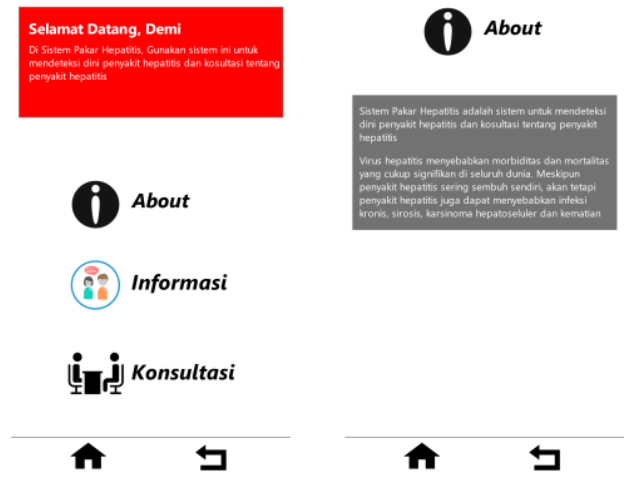

- Design interface information and consultation
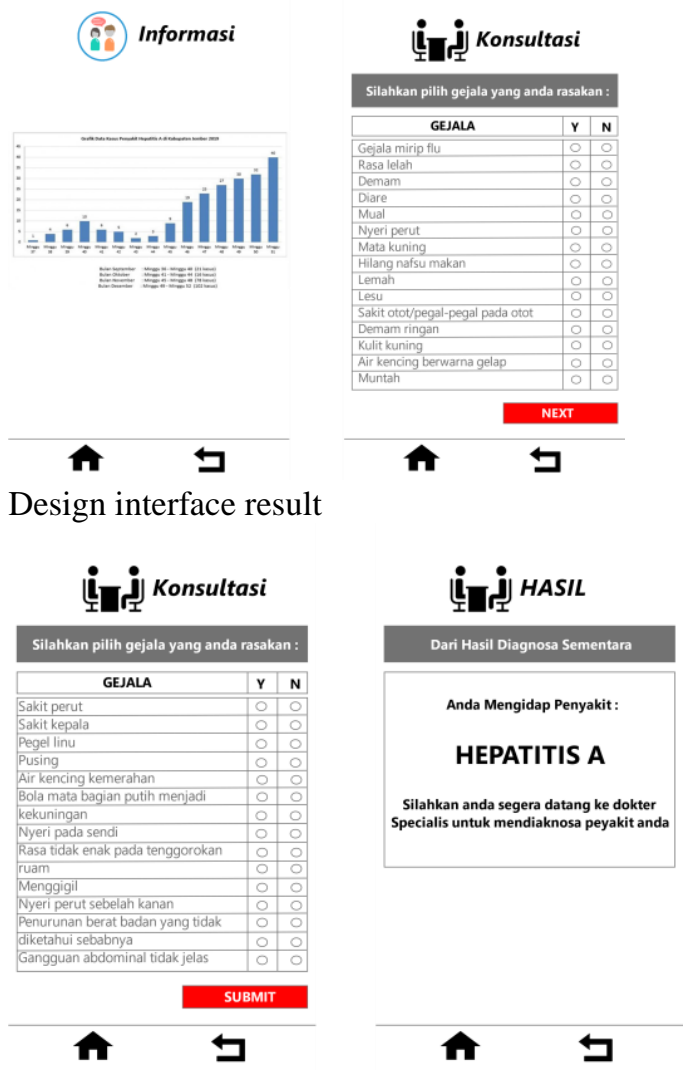

IV. CONCLUSION

Early detection of hepatitis perfectly through a decision support system based on symptom input and laboratory examination results, can apply certainty factor methods for early detection of hepatitis, and decision-making to be made. Adopt the design of a decision-making system.

\section{REFERENCES}

[1] H. Prasetyo and W. Sutopo, "Industri 4.0: Telaah Klasifikasi Aspek Dan Arah Perkembangan Riset," J. Tek. Ind., vol. 13, no. 1, p. 17, 2018, doi: 10.14710/jati.13.1.17-26.

[2] M.A. Ghufron, "Revolusi industri 4.0: tantangan, peluang dan solusi bagi dunia pendidikan," Semin. Nas. dan Disk. Panel Multidisiplin Has. Penelit. Pengabdi. Kpd. Masy., pp. 332-337, 2018.

[3] Y. Lecun, Y. Bengio, and G. Hinton, "Deep learning," Nature, vol. 521, no. 7553, pp. 436-444, 2015, doi: 10.1038/nature14539.

[4] A. Hosny, C. Parmar, J. Quackenbush, L. H. Schwartz, H. J. W. L. Aerts, and H. H. Edu, "Artificial intelligence in radiology," Nat Rev Cancer, vol. 18, no. 8, pp. 500-510, 2018, doi: 10.1038/s41568-0180016-5.

[5] P. F. Aprilliani and H. Mustafidah, "Implementasi Certainty Factor Pada Diagnosa Penyakit Infeksi Tropis,” J. Ris. Sains dan Teknol., vol. 1, no. 1, pp. 22-36, 2017.

[6] World Health Organization, Guidelines on Hepatitis B and C Testing, vol. 66, no. February. 2017.

[7] World Health Organization, Global Heath Sector Strategy on Viral Hepatitis 2016-2021, no. June 2016. 2016.

[8] N. Ratama and Munawaroh, Konsep Kecerdasan Buatan dengan Pemahaman Logika Fuzzy dan Penerapan Aplikasi. Tangerang Selatan: Uwais Inspirasi Indonesia, 2019.

[9] C. P. C. Munaiseche, D. R. Kaparang, and P. T. D. Rompas, "An Expert System for Diagnosing Eye Diseases using Forward Chaining Method," IOP Conf. Ser. Mater. Sci. Eng., 2018, doi: 10.1088/1757$899 X / 306 / 1 / 012023$. 
[10] W. Mohsen and M. T. Levy, "Hepatitis A to E: what's new?," Intern. Med. J., vol. 47, no. 4, pp. 380-389, 2017, doi: 10.1111/imj.13386.

[11] J. Andi, "Pembangunan Aplikasi Child Tracker Berbasis Assisted Global Positioning System ( A-GPS ) Dengan Platform Android," $J$. Ilm. Komput. dan Inform., vol. 1, no. 1, pp. 1-8, 2015, [Online]. Available: elib.unikom.ac.id/download.php?id=300375.
[12] A. Ramdhani, R. R. Isnanto, and I. P. Windasari, "Pengembangan Sistem Pakar Untuk Diagnosis Penyakit Hepatitis Berbasis Web Menggunakan Metode Certainty Factor," J. Teknol. dan Sist. Komput., vol. 3, no. 1, p. 58, 2015, doi: 10.14710/jtsiskom.3.1.2015.58-64.

[13] Noer, S. H.M., Sundoro, and Julitasa, Buku Ajar Ilmu PenyakitHati Edisi Pertama, 1st ed. Jakarta: Jayaabadi, 2007. 